\title{
Developing and Evaluating Neem Leaf Vermiwash as Organic Plant Growth Promoter
}

\author{
B. Jeberlin Prabina*, T. Sivasankari Devi and K. Kumutha \\ Department of Agricultural Microbiology, Agricultural College and Research Institute, Tamil \\ Nadu Agricultural University, Madurai-625 104, Tamil Nadu, India \\ *Corresponding author
}

\begin{abstract}
Keywords
Neem leaf vermiwash,

Microbial count, Growth promoters

Article Info

Accepted:

10 December 2017

Available Online:

10 January 2018 Different substrates namely Prosopis, Albizia, Azadirachta, Azolla, Leucaena, Eichornia and Banana pseudostem were used for preparation of vermicompost along with cowdung (10:1w/w basis). From the active compost, vermiwash was collected @ 40 litres of vermiwash from one complete cycle and different parameters were assessed. Among the different substrates tested, neem leaf vermiwash proved to be a better source of nitrogen fixing, phosphate solubilising, cellulolytic and starch degrading microorganisms. Nitrogen

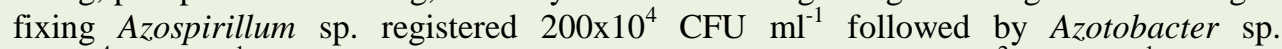
$61 \times 10^{4} \mathrm{CFU} \mathrm{ml}{ }^{-1}$. Phosphorus solubilizing bacteria numbered to $4 \times 10^{2} \mathrm{CFU} \mathrm{ml}^{-1}$ and that of fluorescent Pseudomonads was $37 \times 10^{4} \mathrm{CFU} \mathrm{m}{ }^{-1}$. The cellulose and starch degraders outnumbered the other microbes each with a count of $325 \times 10^{4} \mathrm{CFU} \mathrm{ml}{ }^{-1}$. The nutrient composition of the neem leaf vermiwash was $53.30 \mathrm{ppm}$ of nitrogen, $12 \mathrm{ppm}$ of phosphorus and $223 \mathrm{ppm}$ of potassium. The micronutrients zinc, iron, copper and manganese were present at $0.06,1.08,0.04$ and $0.01 \mathrm{ppm}$ levels. The presence of the plant hormones viz., Indole Acetic Acid (1.25 ppm) and Gibberellic acid $(1.65 \mathrm{ppm})$ added value to the vermiwash. With these diversified biochemical and microbial components, it is concluded that neem leaf vermiwash could be able to sustain the production capacities of soil and that could be developed as an organic supplement for plant growth promotion.
\end{abstract}

\section{A B S T R A C T}

The chemical, biochemical and biological parameters of organic extracts differ from substrates being used for preparation and this work aimed at selecting a suitable substrate for active decomposition of organic wastes with Eisenea sp. and for extraction of vermiwash that could sustain the soil capacities both chemically and biologically.

\section{Introduction}

Modern agricultural practices largely rely on high inputs of mineral fertilizers to achieve high yield and involve applications of chemical pesticides to protect crops against pathogens and pests. These practices are now being re-evaluated and are coming under increased scrutiny as our awareness about the consequences of excessive use of fertilizers and chemical pesticide usage improves. Concerns about the possible consequences of using increased amount of chemicals have led to a strong interest in alternative strategies to ensure competitive yields and protection of crops. This new approach to farming, often 
referred to as sustainable agriculture, seeks to introduce agricultural practices that are friendlier to the environment and that maintain the long-term ecological balance of the soil ecosystem. In this context, the use of microbial inoculants and composted products is considered as the alternate source to meet the nutrient requirement of crops.

The role of earthworms and beneficial microbes in soil formation and soil fertility is well documented and recognized. An approach towards good soil management, with an emphasis on the role of soil inhabitants like earthworms and microorganisms in soil fertility is very important in maintaining the ecosystem. Application of vermicompost, the casting of earthworms favourably affects soil $\mathrm{pH}$, microbial population and soil enzyme activities (Shweta and Singh, 2006).

The castings applied soils contain more of available potassium and ammonium with high water holding capacity (Basker et al., 1993). Application of vermicompost rejuvenates the depleted soil fertility, enriches the available pool of nutrients, maintains soil quality and conserves more water and biological resources. Apart from composting, vermitechnology could be utilized for extraction of vermiwash, a liquid leachate collected by allowing excess water to saturate the actively vermicomposting substrate in such a way that the water washes the nutrients from the vermicast excreted by the earthworms feeding on the substrate as well as the earthworm's body surface (Gopal et al., 2010).

Vermicompost leachate has been reported to be suitable as formulation for liquid fertilizer (Zaller, 2006). The bio-liquid being separated from the saturated vermicast is rich in nutrients and plant growth hormones and its application is shown to increase soil nutrient status and yield of paddy, pulses (Suthar et al.,
2005) and gingelly. Zaller (2006) has reported improved fruit quality of tomato with application of vermiwash and suppression of Phytophthora disease. The treatment of vermiwash in Anthurium has reduced diseases by necrotrophs as well as biotrophs (Karuna $e t$ al., 1999). With many varied beneficial effect with vermiwash, it is important to note that the quality and nutrient content vary with the substrates. This work presents the production of neem leaf vermiwash and its bio-chemical characteristics that it could be exploited as potential organic plant growth promoter.

\section{Materials and Methods}

\section{Collection of vermiwash}

Batch method of vermiwash collection was adopted in an earthen pot provided with an outlet. At the bottom of the pot pebbles were arranged to a height of $3 \mathrm{~cm}$ followed by $3 \mathrm{~cm}$ each coarse gravel and sand forming the vermiwash filtration system. Above this, filtration strata, partially digested substrate + cowdung $(10: 1 \mathrm{w} / \mathrm{w})$ and fresh cow dung, totally weighing $50 \mathrm{~kg}$ were added. The substrates viz., Prosopis, Albizia, Azadirachta, Azolla, Leucaena, Eichornia and Banana pseudostem were moistened to maintain moisture content of $40 \%$. Then about 200 earthworms of Eisenea sp. were added. The collection units were kept undisturbed for ten days. Then another earthen pot of 15litres capacity with a hole at the bottom fitted with a cotton wick was placed over the collection unit. Water was filled in the pot and allowed to trickle through the wick drop by drop and was refilled regularly. Vermiwash was collected till the leachates turned pale compared to the first collect.

The data for neem leaf vermiwash alone is shown as it was found to be bio-chemically better compared to vermiwash from other substrates. 
Isolation, enumeration and characterization of beneficial microbes from neem leaf vermiwash

The different beneficial microbes from the neem leaf vermiwash was isolated using Dilution and Plating Technique using specific medium under aseptic conditions except for Azospirillum sp. Plates/tubes showing best growth for each organism were selected and characterized.

Azospirillum sp. was enumerated with semisolid nitrogen free malic acid medium (Okon et al., 1977) and final purification was done by streaking onto potato infusion agar. Typical pink often wrinkled colonies on potato infusion agar (Baldani and Dobereiner, 1980) were transferred to semi-solid medium for storage and characterization. For characterization Azospirillum sp. isolate (best grown tube) was streaked on $\mathrm{N}$-free agar medium plates (Kreig, 1976) containing 50 mg yeast extract per litre. On this medium, Azospirillum sp. formed small pale green raised colonies. They were then streaked onto potato infusion agar plates (Baldani and Dobereiner, 1980) and Roso congo red agar plates (Rodriguez-Caceres, 1982). Typical pink/white coloured colonies on potato infusion agar and scarlet colonies on Roso congo red agar media were taken as indication that the isolates were Azospirillum sp. The isolates were checked for Gram reaction and found Gram negative.

The mineral phosphate solubilizing bacteria were isolated from vermiwash samples by dilution plating on dicalcium phosphate agar medium (Himedia). The plates were incubated at $28+2^{\circ} \mathrm{C}$ for two to seven days and colonies showing higher solubilizing zone were purified, sub-cultured and maintained on slants of the same medium for further use. The biochemical characterization of the isolates (2 nos) was done as per the procedures outlined by Cappuccino and Sherman (1992). Based on the morphological and bio-chemical characteristics they were identified as Pseudomonas sp., and Bacillus sp.

Fluorescent pseudomonads were isolated using King's B (KB) agar medium (King et al., 1954). The plates were incubated at $30^{\circ} \mathrm{C}$ for $48 \mathrm{~h}$. Colonies that came up on KB plates were observed under UV light on a transilluminator. The green fluorescent colonies under UV light were picked up, purified by repeated streaking on same medium and checked for their fluorescence.

Cellulose degraders were isolated with medium containing $1.0 \%$ peptone, $1.0 \%$ carboxymethylcellulose (CMC), $0.2 \%$ $\mathrm{K}_{2} \mathrm{HPO}_{4}, 1 \%$ agar, $0.03 \% \mathrm{MgSO}_{4} .7 \mathrm{H}_{2} \mathrm{O}$, $0.25 \%\left(\mathrm{NH}_{4}\right)_{2} \mathrm{SO}_{4}$ and $0.2 \%$ gelatin at $\mathrm{pH} 7$ for 48 hours of incubation at $30^{\circ} \mathrm{C}$ (Yin et al., 2010). After incubation for 48 hours, CMC agar plates were flooded with $1 \%$ congo red and allowed to stand for $15 \mathrm{~min}$ at room temperature.

One molar $\mathrm{NaCl}$ was thoroughly used for counterstaining the plates. Clear zones were appeared around growing bacterial colonies indicating cellulose hydrolysis (Andro et al., 1984). The bacterial colonies having the largest clear zone were selected for identification and cellulase production. Based on the morphological and bio-chemical characteristics, the isolate with largest clearing zone was identified as Cellulomonas sp.

Similarly, Starch degrading bacteria was isolated with nutrient agar medium with starch as carbon source. After 48 hrs of incubation plates were flooded with iodine solution (Iodine $-0.2 \%$, Potassium Iodide $-0.4 \%$, Distilled water $-100 \mathrm{ml}$ ). Formation of zone of clearance around the microbial growth indicates the production of amylase. The bacterial colonies having the largest clear zone 
were selected for identification and amylase production. Based on the morphological and bio-chemical characteristics, the isolate with largest clearing zone was identified as Serratia sp.

\section{Chemical analysis of neem leaf vermiwash}

The $\mathrm{pH}$ of the vermiwash was measured with $50 \mathrm{ml}$ of leachate read with a $\mathrm{pH}$ meter. The major and minor soluble nutrients viz., nitrogen, phosphorus, potassium, zinc, iron, copper and manganese were estimated by standard methods. The total sugar of the neem leaf vermiwash was estimated by anthrone method (Hedge and Hofreiter, 1962) and the resulting dark green colour was read at 630 nm (Shimadzu UV 1601 spectrophotometer). The total phenol was estimated using FolinCiocalteau reagent (Bray and Thorpe, 1954) and the blue colour developed was read at 650 nm.

IAA in the neem leaf vermiwash was quantified as described by Gordon and Paleg (1957).Twenty five $\mathrm{ml}$ of the vermiwash was collected and the $\mathrm{pH}$ was adjusted to 2.8 using $1 \mathrm{~N} \mathrm{HCl}$. Equal volume of diethyl ether was added and incubated in dark for four hours. Extraction of IAA was done at $4^{\circ} \mathrm{C}$ in a separating funnel using diethyl either. The organic phase was discarded and the solvent phase was pooled and evaporated to dryness. To the dried matter, two $\mathrm{ml}$ of methanol was added and the IAA present in the methanol extract was determined. To $0.5 \mathrm{ml}$ of methanol extract, $1.5 \mathrm{ml}$ of distilled water and four $\mathrm{ml}$ Sapler's reagent ( $1 \mathrm{ml}$ of $0.5 \mathrm{M} \mathrm{FeCl}_{3}$ in $50 \mathrm{ml}$ of $35 \%$ perchloric acid) were added and incubated in dark for one hour. The intensity of pink colour developed was read at $535 \mathrm{~nm}$ in a UV-VIS spectrophotometer. From a standard curve prepared with known concentrations of IAA, the quantity of IAA in the vermiwash was determined and expressed as $\mu \mathrm{g}$ per $\mathrm{ml}$ of vermiwash.
For GA estimation, twenty five $\mathrm{ml}$ of the vermiwash was taken in a test tube and two ml of zinc acetate was added. After few minutes, two $\mathrm{ml}$ of potassium ferrocyanide was added and centrifuged at $1000 \mathrm{rpm}$ for 15 minutes. To five $\mathrm{ml}$ of this supernatant, five $\mathrm{ml}$ of 30 per cent $\mathrm{HCl}$ was added and incubated at $200^{\circ} \mathrm{C}$ for 75 minutes. The blank sample was treated with five per cent $\mathrm{HCl}$ and the absorbance of the sample as well as blank was measured at $254 \mathrm{~nm}$ in a UV-visible spectrophotometer. The amount of GA present in the extract was calculated from the standard curve and expressed as $\mu \mathrm{g}$ per $\mathrm{ml}$ of the vermiwash.

Testing the antagonism of neem leaf vermiwash extract against fungal pathogens

The fluorescent pseudomonads, Bacillus sp. and Pseudomonas sp. isolates were tested invitro for their bio-control potential using dual inoculation technique (Saktivel and Gnanamanikam, 1987) against three fungal pathogens Fusarium oxysporum, Rhizoctonia solani and Sclerotium rolfsii on PDA agar medium. The fungal pathogens were grown separately on PDA plates till the hypha cover the whole surface of the agar. With the help of sterile cork borer, a disc of fungal growth from these plates was placed at the centre of the fresh PDA plate. Each bacterial strain was then streaked in a parallel manner on either side of the fungal disc and kept for incubation at $30^{\circ} \mathrm{C}$ for 96 hours. Observations on the inhibition of growth of fungal pathogen were recorded after 96 hours of incubation in comparison with the PDA plate inoculated with only the pathogens. The radial growth of mycelium was measured and per cent inhibition (PI) was calculated

Per cent inhibition $(\mathrm{PI})=\mathrm{PI}=\mathrm{C}-\mathrm{T} / \mathrm{C} \times 100$

Where, $\mathrm{C}$ is the growth of test pathogen $(\mathrm{cm})$ in the absence of the antagonistic strain, $\mathrm{T}$ is 
the growth of test pathogen $(\mathrm{cm})$ in the presence of the antagonistic strain.

\section{Results and Discussion}

\section{Collection of vermiwash}

From the vermiwash collection units about 10 -12 litres of vermiwash from different substrates namely Prosopis, Albizia, Azadirachta, Azolla, Leucaena, Eichornia and Banana pseudostem were collected during the first draw after 30 days period. The vermiwash collections were clear and the colour was dark brown for Azadirachta, Azolla, Eichornia and Banana pseudostem. The colour was light brown for Prosopis, Albizia and Leucaena. When the colour of the vermiwash has turned pale and the substrate level has gone down to almost half the height of the barrel the collection was stopped. About 40 litres of vermiwash was collected from one complete run of the unit.

\section{Growth promoting bio-chemical constituents of neem leaf vermiwash}

The $\mathrm{pH}$ of neem leaf vermiwash varied between 7.6 and 8.2 that it could be ideally used for soil and crop application. The beneficial microbes namely Azospirillum sp., phosphorus solubilizing bacteria, fluorescent Pseudomonads, cellulose and starch degraders were enumerated and the results are tabulated in Table 1.

On analysis of neem leaf vermiwash it proved to be a better source of nitrogen fixing, phosphate solubilising, cellulolytic and starch degrading microorganisms. Nitrogen fixing Azospirillum sp. registered a population of 200x $10^{4} \mathrm{CFU} \mathrm{ml}^{-1}$ followed by Azotobacter sp. $61 \times 10^{4} \mathrm{CFU} \mathrm{ml^{-1 }}$. Phosphorus solubilizing bacteria numbered to $4 \times 10^{2} \mathrm{CFU} \mathrm{ml}^{-1}$ and that of fluorescent Pseudomonads was $37 \times 10^{4} \mathrm{CFU}$ $\mathrm{ml}^{-1}$.
The cellulose and starch degraders outnumbered the other microbes with a population of $325 \times 10^{4} \mathrm{CFU} \mathrm{ml}{ }^{-1}$ each. Gopal et al., (2010) reported a total bacterial count of $2 \times 10^{4}$, phosphate solubilizers count of $2 \times 10^{2}$, Pseudomonads count of $8 \times 10^{2}$ in coconut leaf vermiwash. The microbial load in vermiwash could be attributed for their capacity in increasing the soil fertility and crop growth. The nutrient content of neem leaf vermiwash was analysed and found to be $53.30 \mathrm{ppm}$ of nitrogen, $12.00 \mathrm{ppm}$ of phosphorus and 223.00 ppm of potassium.

The nutrient content of the vermiwash collected from the control i.e., cowdung alone was 59.00, 20.00, 193.00 ppm respectively. Gopal et al., (2010) developed coconut leaf vermiwash with Eudrilus sp. and found that the nitrogen content in coconut leaf vermiwash $(2.80 \mathrm{ppm})$ was much lesser than the vermiwash collected from cowdung $(61 \mathrm{ppm})$ and concluded that the variation was due to nitrogen losses through assimilation, rapid nitrification and de-nitrification by the nitrifying and denitrifying bacteria.

The nitrogen loss due to rapid nitrification could be controlled by application of neem based products along with the nitrogen fertilizers. Neem coated urea with the help of the neem triterpenes when applied to the soil, inhibit the activity of nitrifying bacteria viz., Nitrosomonas sp., Nitrobacter sp. resulting in delayed transformation of ammoniacal nitrogen into nitrite nitrogen thus ensuring slow and continuous availability of nitrogen throughout the crop period (Mohanty et al., 2008). Zaller (2006) reported drastic reduction in total nitrogen content from 640 to $48.06 \mathrm{mg}$ $1^{-1}$ from vermiwash collect with fruits and vegetable waste. Opoku (2014) reported increased $\mathrm{NH}_{4}{ }^{+}$accumulation by $8.9 \mathrm{mg} \mathrm{kg}^{-1}$ and decreased $\mathrm{NO}_{3}^{-}$by $13.5 \mathrm{mg} \mathrm{kg}^{-1}$ within a month with the application of neem seed oil along with crop residues. In the present study, 
the available nitrogen content of the neem leaf in inhibiting the nitrogen loss that is apparent vermiwash was $53.30 \mathrm{ppm}$ and that of from the nitrogen content in the leachates of vermiwash from cowdung was $59.00 \mathrm{ppm}$. neem leaf vermicompost $(53.30 \mathrm{ppm})$ and This result highlighted the influence of neem cowdung compost $(59.00 \mathrm{ppm})$.

Table.1 Population of beneficial microbes isolated from neem leaf vermiwash

\begin{tabular}{|c|c|c|c|c|c|c|}
\hline & $\begin{array}{c}\text { Azospirill } \\
\text { um sp } \\
\left(\mathrm{CFUml}^{-1}\right)\end{array}$ & $\begin{array}{c}\text { Azotobact } \\
\text { er sp } \\
\left(\text { CFUml }^{-1}\right)\end{array}$ & $\begin{array}{l}\text { Phospho } \\
\text { Bacteria* } \\
\left(\text { CFUml }^{-1}\right)\end{array}$ & $\begin{array}{c}\text { Fluorescent } \\
\text { Pseudomon } \\
\text { ads } \\
\left(\mathrm{CFUml}^{-1}\right)\end{array}$ & $\begin{array}{l}\text { Cellulolytic } \\
\text { bacteria*** } \\
\left(\mathrm{CFUml} \mathbf{H}^{-1}\right)\end{array}$ & $\begin{array}{c}\text { Starch } \\
\text { degrading } \\
\text { bacteria }^{* * * * *} \\
\left(\text { CFUml }^{-1}\right)\end{array}$ \\
\hline 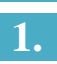 & $54 \times 10^{2}$ & $200 \times 10^{4}$ & $4 \times 10^{2}$ & $37 \times 10^{4}$ & $325 \times 10^{4}$ & $325 \times 10^{4}$ \\
\hline
\end{tabular}

*Pseudomonas sp. and Bacillus sp; **Cellulomonas sp.;**Serratia sp. CFU - Colony Forming Units

Table.2 Chemical constituents of neem leaf vermiwash

\begin{tabular}{|c|c|c|c|c|c|c|c|}
\hline pH & $\begin{array}{c}\mathbf{N} \\
(\mathrm{ppm})\end{array}$ & $\begin{array}{c}\mathbf{P} \\
(\mathrm{ppm})\end{array}$ & $\begin{array}{c}\mathrm{K} \\
(\mathrm{ppm})\end{array}$ & $\begin{array}{c}\mathrm{Zn} \\
(\mathrm{ppm})\end{array}$ & $\begin{array}{c}\mathrm{Fe} \\
(\mathrm{ppm})\end{array}$ & $\begin{array}{c}\mathrm{Cu} \\
(\mathrm{ppm})\end{array}$ & $\begin{array}{c}\text { Mn } \\
(\mathbf{p p m})\end{array}$ \\
\hline $7.6-8.2$ & 53.30 & 12.00 & 223.00 & 0.06 & 1.08 & 0.04 & 0.01 \\
\hline $\begin{array}{c}\text { Total } \\
\text { sugars } \\
(\mathbf{p p m})\end{array}$ & $\begin{array}{c}\text { Total } \\
\text { phenols } \\
(\mathrm{ppm})\end{array}$ & $\begin{array}{c}\text { IAA } \\
(\mathrm{ppm})\end{array}$ & $\begin{array}{c}\mathbf{G A} \\
(\mathrm{ppm})\end{array}$ & & & & \\
\hline 72 & 12.10 & 1.25 & 1.65 & & & & \\
\hline
\end{tabular}

Table.3 Bio-control potential of the bacterial isolates from neem leaf vermiwash

\begin{tabular}{|l|c|c|c|c|c|c|}
\hline & \multicolumn{2}{|l|}{ Fusarium oxysporum } & \multicolumn{2}{|l|}{ Rhizoctonia solani } & \multicolumn{2}{|c|}{ Sclerotium rolfsii } \\
\hline Isolate & $\begin{array}{c}\text { Inhibition } \\
\text { zone }(\mathrm{cm})\end{array}$ & $\begin{array}{c}\text { Per cent } \\
\text { Inhibition } \\
(\mathrm{PI})\end{array}$ & $\begin{array}{c}\text { Inhibition } \\
\text { zone }(\mathrm{cm})\end{array}$ & $\begin{array}{c}\text { Per cent } \\
\text { Inhibition } \\
(\mathrm{PI})\end{array}$ & $\begin{array}{c}\text { Inhibition } \\
\text { zone }(\mathrm{cm})\end{array}$ & $\begin{array}{c}\text { Per cent } \\
\text { Inhibition } \\
(\mathrm{PI})\end{array}$ \\
\hline $\begin{array}{l}\text { Phosphorus } \\
\text { solubiliving } \\
\text { Pseudomonas sp. }\end{array}$ & 5.10 & 76.47 & 5.90 & 52.00 & nil & nil \\
\hline $\begin{array}{l}\text { Phosphorus } \\
\text { solubilizing }\end{array}$ & 4.90 & 42.86 & nil & nil & nil & nil \\
\hline \begin{tabular}{l} 
Bacillus sp. \\
\hline $\begin{array}{l}\text { Fluorescent } \\
\text { Pseudomonads }\end{array}$
\end{tabular} & 4.40 & 65.90 & 4.10 & 78.00 & 4.8 & 52.00 \\
\hline
\end{tabular}

The micronutrients zinc, iron, copper and manganese were present at $0.06,1.08,0.04$ and $0.01 \mathrm{ppm}$ levels. The wash from coconut leaf had 2.80, 10.28 and 205.00 ppm of N, P, $\mathrm{K}$ respectively (Gopal et al., 2010).
Vermiwash from fruit and vegetable wastes was reported to have about $3.08 \pm 0.10 \mathrm{ppm}$ of phosphorus, $60.49 \pm 1.94 \mathrm{ppm}$ of potassium, $58.91 \pm 2.62 \mathrm{ppm}$ of calcium and $18.19 \pm 0.58 \mathrm{ppm}$ of magnesium (Zaller, 
2006). The beneficial microbes are known to produce plant growth promoting substances. The phyto-hormones synthesized by microbes influence root hair development, respiration rate, metabolism and root proliferation which in turn results in better mineral uptake (Bar and Okon, 1993). The presence of IAA and $G A$ in the neem leaf vermiwash was exclusively due to the activity of beneficial microbes present in the vermiwash and more particularly with the characterized isolates viz., Azospirillum sp. Bacillus sp. and fluorescent Pseudomonads that are potential growth promoters. It was demonstrated that soil application of vermiwash in ornamental plants could bring similar effect as that of auxins, gibberellins and cytokinins (Tomati and Galli 1995). Hernandez et al., (1996) recorded increased biomass accumulation of Panicum maximum and concluded that the increase was due to IAA released by Azospirillum sp. Production of considerable amount of IAA and GA by phosphorus solubilizing Bacillus polymyxa, Bacillus pulvifaciens and Pseudomonas striata was reported by Gaur (1990). The presence of IAA and GA in the neem leaf vermiwash proved that it would be good source of growth promoting substances.

Regarding the potential of the bacterial isolates in controlling the pathogens, the three isolates viz., phosphorus solubilizing Pseudomonas sp. and Bacillus sp. and fluorescent Pseudomonads showed inhibitory action against Fusarium oxysporum, Rhizoctonia solani and Sclerotium rolfsii. In the present study, all the three isolates viz., phosphorus solubilizing Pseudomonas sp. and Bacillus sp. and fluorescent Pseudomonads showed inhibition against Fusarium oxysporum with a higher inhibition per cent of 76.47 by phosphorus solubilizing Pseudomonas sp. Rhizoctonia solani was inhibited by both phosphorus solubilizing Pseudomonas sp. and fluorescent
Pseudomonads. Fluorescent Pseudomonads inhibited the growth of Sclerotium rolfsii with an inhibition per cent of 52 .

This study has clearly brought an insight about the characteristics of neem leaf vermiwash that it could be applied to crops for growth promotion and to soil for sustaining the productivity. Plant bio-assay to study the influence of neem leaf vermiwash. The effect of neem leaf vermiwash

\section{References}

Andro, T, J. P Chambost, A. Kotoujansky, Y. Bertheau, F. Barras, F. Van Gijsegam and A. J. Coleno, 1984. Mutants of Erwinia chrysanthemi defective in secretion of pectinase and cellulase. J Bacteriol., 160: 1199.

Baldani, V. D.L., and J. Dobereiner. 1980. Host plant specificity in the infection of cereals with Azospirillum spp. Soil Biol. Biochem., 12: 433.

Bar, T., and Y. Okon. 1993. Tryptophan conversion to indole-acetic acid via indole3-acetamide in Azospirillum brasilense sp7, Can. J. Microbiol., 39: 81.

Basker, A., A. N. Macgregor and J. H. Kirman. 1993. Exchangeable potassium and other cations in non-digested soil and cast of two species of pasture earthworms, Soil Biol. Biochem., 25: 1673.

Bray, H. G., and W. V. Thorpe. 1954. Analysis of phenolic compounds of interest in metabolism. Meth. Biochem. Anal., 27.

Cappuccino, J.G and N. Sherman 1992. Microbiology: A laboratory Manual. The Benjamin/Cummings Publishing Company, Inc., California.

Gaur, A. C., 1990. Phosphate solubilizing microorganisms as Biofertilizers, Omega Scientific Publishers, New Delhi) pp. 176.

Gopal, M., A. Gupta C. Palaniswami R. Dhanapal and G. V. Thomas. 2010. Coconut leaf vermiwash: a bio-liquid from coconut leaf vermicompost for improving the crop production capacities of soil, Curr Sci., 98: 1202. 
Gordon, S. A., and L. G. Paleg. 1957. Quantitative measurement of indole acetic acid $\mathrm{Pl}$. Physiol., 1037.

Hedge, J. E., and B. T. Hofreiter. 1962. In Carbohydrate Chemistry edited by $\mathrm{R} \mathrm{L}$ Whistler and J N BeMiller, Academic Press New York.

Hernandez, Y., M. Sarmiento and O. Garcia. 1996. Influence of the Azospirillum inoculation model on grass performance. Cuban J. Agric. Sci., 30: 219.

Karuna, K., C. R. Patil, P. Narayanswamy and R. D Kale. 1999. Stimulatory effect of earthworm body fluid (vermiwash) on crinkle red variety of Anthurium andreanum Lind, Crop Res., 17(2): 253.

King, E. O., M. K. Ward and D. W. Raney. 1954. Two simple media for the demonstration of pyocyanin and fluorescin, J. Lab. Clin. Med., 36: 100.

Kreig, N. H., 1976. The genera Spirillum, Aquaspirillum and Oceanospirillum, in The Prokarytes, A Handbook on Habitats, Isolation and Identification Bacteria, edited by M P Stass, H Stolp, H G Truper, A Balonis and H G Schlegal, Springer Verlag, Berlin, Heidelberg, New York, 595.

Mohanty, S., A. K. Patra, and P. K. Chhonkar. 2008. Neem (Azadirachta indica) seed kernel powder retards urease and nitrification activities in different soils at contrasting moisture and temperature regimes. Bioresource Technol., 99: 894.

Okon,Y., S.L. Albrecht and R.H Burris. 1977. Methods for growing Spirillum lipoferum and for counting it in pure culture and in association with plants, Appl Environ
Microbiol., 33: 85.

Opoku, A., B. Chaves and Stefaan De Neve and U. Gent. 2014. Neem seed oil: a potent nitrification inhibitor to control nitrate leaching after incorporation of crop residues. Biol Agric Hortic, 30:145.

Rodreiguez Caceres, E. A. 1982. Improved medium for isolation of Azospirillum spp, Appl. Envion. Microbiol., 44: 990.

Sakthivel, N., and S. S. Gnanamanickam. 1987. Evaluation of Pseudomonas fluorescens for suppression of sheath rot disease and enhancement of grain yields in rice (Oryza sativa L), Appl. Environ. Microbiol., 2056.

Shweta, K. K., and Y. P. Singh. 2006. Efficacy of vermicompost and plant growth promoter on Tagetes erecta A.L, Asian Jr. Microbiol. Biotech. Env. Sci., 8: 831.

Suthar, S., R. Choyal, S. Singh and R. Sudesh. 2005. Stimulatory effect of earthworm body fluid (vermiwash) on seed germination and seedling growth of two legumes, Journal Phytol Res., 18: 219.

Tomati, U., and E. Galli. 1995. Earthworm, soil fertility and plant productivity. Acta Zoologica Fennica, 196: 11.

Yin, L.J., P. S. Huang and H. H. Lin. 2010. Isolation of cellulose producing bacteria and characterization of the cellulase from the isolated bacterium Cellulomonas sp, J Agric Food Chem., 58: 9833.

Zaller, J. G., 2006. Foliar spray of vermicompost extracts: effects on fruit quality and indications of late-blight suppression on field grown tomatoes, Biol. Agric. Hortic., 24: 165.

\section{How to cite this article:}

Jeberlin Prabina, B., T. Sivasankari Devi and Kumutha, K. 2018. Developing and Evaluating Neem Leaf Vermiwash as Organic Plant Growth Promoter. Int.J.Curr.Microbiol.App.Sci. 7(01): 859-866. doi: https://doi.org/10.20546/ijcmas.2018.701.104 